\title{
DEMOKRASI INDONESIA PASCA AMANDEMEN UUD NRI TAHUN 1945 DALAM PERSPEKTIF LEGISLASI
}

(Indonesia Democracy After UUD NRI 1945 Amendment On Legislative Perspective)

\author{
Rachmat Trijono \\ Badan Pembinaan Hukum Nasional Kementerian Hukum dan HAM RI \\ Alamat: Mayjend. Sutoyo No. 10 Cililitan Jakarta Timur \\ Email: Ikpi.179@gmail.com
}

Naskah diterima: 9 Desember 2013; revisi: 10 Desember 2013; disetujui: 17 Desember 2013

\begin{abstract}
Abstrak
Indikator mengkualifikasikan praktek demokrasi Indonesia adalah fungsi lembaga perwakilan rakyat yakni Dewan Perwakilan Rakyat dan Dewan Perwakilan Daerah. Semakin lembaga perwakilan rakyat tersebut berfungsi, maka Indonesia semakin demokratis. Persoalan yang diteliti dan dijawab adalah bagaimana demokrasi Indonesia pasca amandemen dalam perspektif pembentukan undang-undang. Penelitian ini mempergunakan metode penelitian normatif, yang bersifat deskriptif, dengan menggunakan bahan pustaka yang berupa data sekunder sebagai sumber utamanya. Hasil penelitian menunjukkan bahwa Indonesia pada masa pasca amandemen UUD NRI Tahun 1945 belum dapat dikatakan sebagai negara yang demokratis. Untuk itu ke depan diharapkan dengan amandemen kelima UUD NRI Tahun 1945, Indonesia akan lebih demokratis.
\end{abstract}

Kata Kunci: demokrasi, amandemen, legislasi

\begin{abstract}
Indicator to qualify the practice of Indonesia democracy is the function of the parliament that is House of Representative (DPR) and Local Representative (DPD). The more function of parliament, so the more democratic in Indonesia. The problem which are researched and answered is how democracy in Indonesia after the amendment in the law making perspective. This research is used in normative research method, descriptive, by using library materials in the form of secondary data as the main source. The results of the research showed that Indonesia in the period after constitution (UUD NRI 1945) amendment cannot be said to be a democratic state. For the future it is expected by the fifth constitution amendment, Indonesia will be more democratic.
\end{abstract}

Keywords: democracy, the amendment, legislation 


\section{A. Pendahuluan}

Demokrasi Indonesia adalah demokrasi berdasarkan pancasila dan masih dalam taraf perkembangan. Dalam sejarah perkembangan demokrasi, Indonesia mengenal bermacammacam istilah demokrasi, antara lain demokrasi konstitusional, demokrasi parlementer, demokrasi terpimpin, demokrasi pancasila, dan sebagainya. Semua konsep tersebut memakai istilah demokrasi.

Hasil penelitian UNESCO tahun 1949 menunjukkan bahwa demokrasi dinyatakan sebagai nama yang paling baik dan wajar untuk semua sistem organisasi politik dan sosial yang diperjuangkan (probably for the first time in history democracy is claimed as the proper ideal description of all systems of political and social organization advocated by in fluent proponents). ${ }^{1}$ Disamping itu UNESCO juga berpendapat bahwa ide demokrasi dianggap ambiguous atau mempunyai berbagai pengertian mengenai lembaga-lembaga atau cara-cara yang dipakai untuk melaksanakan ide, atau mengenai keadaan kultural serta historis yang mempengaruhi istilah, ide dan praktik demokrasi (either in the institutions or devices employed to effect the idea or in the cultural or historical circumstances by which word, idea, and practice are conditioned). ${ }^{2}$

Pertanyaan mendasar dari para mahasiswa sering terlontar dalam sistem PBM di kelas, yaitu apakah Indonesia termasuk dalam negara yang demokratis atau bukan. Jawaban pertanyaan tersebut tergantung pada reasoning para mahasiswa. Bagi mereka yang reasoningnya pro terhadap demokratis, maka Indonesia dapat dikategorikan sebagai negara yang demokratis. namun jika menggunakan reasoning yang kontra demokratis, maka Indonesia digolongkan sebagai negara yang non demokratis.

Untuk itulah penting diadakan penelitian mengenai posisi Indonesia sebagai negara yang demokratis atau sebagai negara yang non demokratis, ditinjau dari proses pembentukan undang-undang, terutama proses pembahasannya.

\section{B. Permasalahan}

Penelitian ini terfokus pada demokrasi Indonesia dalam perspektif pembentukan undang-undang pasca amandemen. Untuk itu, persoalan yang diteliti dan dijawab adalah bagaimana demokrasi Indonesia pasca amandemen dalam perspektif pembentukan undang-undang. Hal ini penting mengingat bahwa Indonesia adalah negara demokratis yang diselenggarakan berdasarkan representative democratic.

\section{Metode Penelitian}

Penelitian ini mempergunakan metode penelitian normatif, ${ }^{3}$ yang bersifat deskriptif. Penelitian ini menggunakan bahan pustaka yang berupa data sekunder sebagai sumber utamanya, yang mencakup:* (a) Bahan Hukum Primer, yaitu Undang Undang Dasar 1945, Undang-Undang Nomor 12 Tahun 2011, UndangUndang Nomor 27 Tahun 2009 tentang Majelis

\footnotetext{
S.I. Benn dan Peters, Principles of Political Thought (New York: Collier Books; 1964), hlm. 393.

Ibid.

Soerjono Soekanto dan Sri Mamuji, Penelitian Hukum Normatif,Suatu Tinjauan Singkat (Jakarta: CV. Rajawali, 1990), hlm. 15.

$4 \quad$ Ibid, hlm 14-15.
} 
Permusyawaratan Rakyat, Dewan Perwakilan Rakyat, Dewan Perwakilan Daerah, dan Dewan Perwakilan Rakyat Daerah, Putusan Mahkamah Konstitusi Nomor 92/PUU-X/2012. (b) Bahan Hukum Sekunder, berupa literatur, makalah, penelitian dan (c) Bahan hukum tertier, berupa Kamus Besar Bahasa Indonesia.

Berbagai data tersebut dapat diperoleh baik melalui studi pustaka maupun penelusuran data melalui internet. Pengumpulan data-data tersebut saling memberikan verifikasi, koreksi, perlengkapan dan pemerincian. ${ }^{5}$ Setelah terkumpul, dianalisis secara kwalitatif. ${ }^{6}$

\section{Pembahasan}

\section{Kerangka Pemikiran}

Pemikiran teoritis sebagai penuntun penulis dalam penelitian ini diawali dengan pemahaman bahwa negara demokrasi adalah negara yang diselenggarakan berdasarkan kehendak dan kemauan rakyat. Dengan demikian, dari sudut pandang pembentukan undang-undang, maka negara yang demokratis adalah negara yang dalam pembentukan undang-undangnya berdasarkan kehendak dan kemauan rakyat. Agar kehendak dan kemauan rakyat terpenuhi, maka lembaga legislatif harus berfungsi dengan baik. Dengan demikian semakin lembaga perwakilan rakyat tersebut berfungsi, maka
Indonesia semakin demokratis, atau dengan kata lain semakin banyak melibatkan rakyat dalam keputusan politik yang berkaitan dengan kepentingan rakyat adalah mencerminkan telah makin membaiknya pelaksanaan demokrasi di negara yang bersangkutan.

\section{Konsepsional}

Beberapa konsepsional tersimpul dalam penggunaan istilah-istilah atau frasa-frasa sebagai berikut: Demokrasi Indonesia, Pasca Amandemen.

a. Demokrasi Indonesia secara formil adalah Demokrasi Pancasila. Pelaksanaan Demokrasi Pancasila dihubungkan dengan prakteknya pasca amandemen dalam perspektif pembentukan undang-undang di Indonesia, ditandai dengan beberapa indikator. Secara spesifik, indikator yang digunakan untuk mengkualifikasikan praktek demokrasi Pancasila adalah fungsi lembaga perwakilan rakyat, yakni apakah lembaga perwakilan rakyat tersebut berfungi atau tidak, artinya bahwa semakin lembaga perwakilan rakyat tersebut berfungi, maka Indonesia semakin demokratis, atau semakin banyak melibatkan rakyat dalam keputusan politik yang berkaitan dengan kepentingan rakyat adalah mencerminkan

Anton Bakker dan Achmad Charris Zubair, Metodologi Penelitian Filsafat (Yogyakarta: Kanisius, 1990), hlm. 94.

"Qualitative research we mean any kind of research that procedure findings not arrived at by mean of statistic procedures or other mean of quantifications. It can refer to research about persons' lives, stories, behaviors, but also about organizations. Functioning, social covenants or intellectual relationship", Anselmus Strauss and Juliat Corbin, Basic of Qualititive Research, Grounded Theory Procedure and Thechnique (New Delhi: Sage Publication, Newbury, Park London, 1979), hlm 17. Mengenai Penelitian Kualitatif Lexy J Moleong membuat karya yang diterbitkan dengan judul Metodologi Penelitian Kualitatif (Bandung: PT Remaja Rosdakarya, 1989); juga John W Creswell, Research Design: Qualitative \& Quantitative Approaches (New Delhi: Sage Publication,Thousand Oaks, London, 1994); Robert Bogdan and Steven J. Taylor, Introduction to qualitative Research Methods: A Phenomenological Approach To The Social Science (New York: A Willey-Interscience Publication, 1975); Michael Quinn Patton, Qualitative Evaluation And Research Methods, Second Edition (New Delhi: Sage Publication, Newbury Park London, 1980). 
telah makin membaiknya pelaksanaan demokrasi di negara yang bersangkutan.

b. Pengertian pasca adalah sesudah ${ }^{7}$ dan amandemen adalah penambahan pada bagian yang sudah ada ${ }^{8}$ terhadap UUD 1945. Dengan demikian yang dimaksud dengan pasca amandemen adalah sesudah adanya penambahan pada UUD 1945.

c. Mengenai Legislasi, Jimly Asshidiqie mengemukakan bahwa seringkali dipahami bahwa fungsi legislasi hanya terkait dengan fungsi pembuatan undang-undang dalam pengertian yang sempit. ${ }^{9}$

\section{Kerangka Teori}

Dalam sistem demokrasi dan negara hukum modern, sudah umum diketahui bahwa kekuasaan negara dibagi dan dipisah-pisahkan antara cabang-cabang kekuasaan legislatif, eksekutif dan yudikatif. Pada pokoknya, kekuasaan untuk atau membuat aturan dalam kehidupan bernegara dikonstruksikan berasal dari rakyat yang berdaulat yang dilembagakan dalam organisasi negara di lembaga legislatif sebagai lembaga perwakilan rakyat. Sedangkan cabang kekuasaan pemerintahan negara sebagai organ pelaksana atau eksekutif hanya menjalnkan peraturan-peraturanyang ditetpkan oleh cabang legislatif. Sementar itu, cabang kekuasaan kehakiman atau judikatif bertindak sebagai pihak yang menegakkan peraturan- peraturan itu melalui proses peradilan yang independen dan imparsial. ${ }^{10}$

Dengan paradigma pemikiran yang demikin, maka satu-satunya sumber legitimasi organ negara untuk menetapkan sesuatu norma hukum yang berbentuk peraturan (regeling) adalah organ yang bekerja di cabang kekuasan legislatif. ${ }^{11}$

Berdasarkan pemahaman di atas, penelitian ini didasarkan pada acuan teori Sistem Kamar di lembaga perwakilan rakyat, teori Pembagian Kekuasaan, dan teori Pembentukan Undangundang.

\section{a. Teori Sistem Kamar di Lembaga Perwakilan Rakyat}

Sistem lembaga perwakilan rakyat berbeda darisatu negara dengan negaralainnya. Beberapa negara menggunakan sistem bikameral dan beberapa negara lain menggunakan sistem unikameral. Hal ini sebagaimana dikemukakan oleh Miriam Budiardjo sebagai berikut: ${ }^{12}$

"Ada negara negara dimana badan legislatif
terbagi dalam dua majelis (bi-kameralisme),
sedangkan di beberapa negara lain hanya
terdiri dari satu majelis (uni-kameralisme).
Boleh dikatakan bahwa semua negara federal
memakai sistem dua majelis oleh karena
satu diantaranya mewakili kepentingan
negara bagian khususnya (India, Amerika
Serikat, Uni Soviet, Republik Indonesia
Serikat). Negara kesatuan yang memakai
sistem dua majelis biasanya terdorong oleh
pertimbangan bahwa satu majelis dapat 
mengimbangi dan membatasi kekuasaan dari majelis lain. Dikuatirkan bahwa sistem satu majelis memberi peluang untuk menyalahgunakan kekuasaan oleh karena mudah dipengaruhi oleh situasi politik. Bagaimanapun juga, majelis tambahan biasanya disusun sedemikian rupa sehingga wewenangnya kurang daripada badan yang mewakili rakyat. Badan yang mewakili rakyat umumnya disebut Majelis Rendah (Lower House) sedangkan majelis lainnya disebut Majelis Tinggi (Upper House atau Senat)."

\section{b. Teori Pembatasan Kekuasaan}

Dalam Undang Undang Dasar 1945 ditentukan bahwa Indonesia merupakan negara yang berkedaulatan rakyat $^{13}$ dengan berdasarkan atas hukum ${ }^{14}$. Hal ini menurut Jimly Asshiddiqie ${ }^{15}$ bahwa gagasan negara demokrasi atau kedaulatan rakyat disebut pula dengan istilah constitutional democracy yang dihubungkan dengan pengertian negara demokrasi yang berdasarkan hukum.

Sebagai ciri pokok dari negara hukum, adalah adanya elemen pembatasan kekuasaan. Untuk itulah ide pembatasan kekuasaan itu dianggap mutlak harus ada. ${ }^{16}$ Pembatasan kekuasaan berkaitan erat dengan teori pemisahan kekuasaan dan teori pembagian kekuasaan. ${ }^{17}$

\section{1) Pemisahan Kekuasaan}

Istilah "pemisahan kekuasaan" dalam bahasa Indonesia merupakan terjemahan perkataan separation of power, berdasarkan teori trias politica atau tiga fungsi kekuasaan yang dalam pandangan Monteesquieu, harus dibedakan dan dipisahkan secara struktural dalam organ-organ yang tidak saling mencampuri urusan masingmasing. ${ }^{18}$ Menurut Montesquieu dalam bukunya L'Esprit des Lois, bahwa: ${ }^{19}$ kekuasaan negara dibagi dalam tiga cabang yaitu (1) kekuasaan legislatif sebagai pembuat undang-undang; (2) kekuasaan eksekutif yang melaksanakan; dan (iii) kekuasaan untuk menghakimi atau yudikatif.

\section{2) Pembagian Kekuasaan}

Pembagian kekuasaan terdiri dari dua kata, yaitu "pembagian" dan "kekuasaan". Menurut Kamus Besar Bahasa Indonesia $(\mathrm{KBBI})$, pembagian memiliki pengertian proses menceraikan menjadi beberapa bagian atau memecahkan (sesuatu) lalu memberikannya kepada pihak lain. ${ }^{20}$ Sedangkan kekuasaan adalah wewenang atas sesuatu atau untuk menentukan (memerintah, mewakili, mengurus, dan sebagainya) sesuatu. ${ }^{21}$

Moh. Kusnardi dan Harmaily Ibrahim memaknai pembagian kekuasaan berarti bahwa kekuasaan itu memang dibagi-bagi dalam beberapa bagian (legislatif, eksekutif dan yudikatif), tetapi tidak dipisahkan. Hal ini membawa konsekuensi bahwa diantara bagian-

\footnotetext{
Pasal 1 ayat (3) UUD NRI Tahun 1945.

Ibid., Pasal 1 ayat (3).

Jimly Asshiddiqie, Pengantar Ilmu Hukum Tata Negara, (Jakarta: PT Rajagrafindo Persada, 2013), hlm. 281.

Ibid., hlm. 282.

Ibid., hlm. 284.

Ibid., hlm. 285.

9 O. HoodPhilips, Paul Jackson, and Patricia Leopold, Constitution and Administrative Law (London: Sweet \& Maxwell, 2001), hlm. 10-11.

20 Dendy Sugono, Kamus Bahasa Indonesia (Jakarta: Pusat Bahasa Departemen Pendidikan Nasional, 2008), hlm. 114.

$21 \quad$ Ibid., hlm. 824.
} 
bagian itu dimungkinkan ada koordinasi atau kerjasama. ${ }^{22}$

Selanjutnya ditegaskan bahwa: ${ }^{23}$ kalau dalam Undang Undang Dasar suatu negara dari ketiga kekuasaan yang dibagi itu ternyata dalam kenyataannya tidak terdapat pemisahan kekuasaan, karena umpamanya Undang Undangnya dibuat oleh Eksekutif dan Legislatif, maka Undang Undang Dasar tersebut dikatakan menganut asas pembagian kekuasaan.

\section{c. Teori Pembentukan Undang Undang \\ 1) Pengertian Undang-undang}

Lembaga perwakilan rakyat atau parlemen atau lembaga legislatif merupakan kekuasaan yang pertama-tama mencerminkan kedaulatan rakyat. Kegiatan bernegara, pertama-tama adalah untuk mengatur kehidupan bersama. Oleh sebab itu kewenangan untuk menetapkan peraturan itu pertama-tama harus diberikan kepada lembaga perwakilan rakyat atau parlemen atau lembga legislatif. ${ }^{24}$

Oleh karena itu, yang biasa disebut sebagai fungsi pertama lembaga perwakilan rakyat adalah fungsi legislasi atau pengaturan. Dalam bentuk konkretnya, fungsi pengaturan (regelende functie) ini terwujud dalam fungsi pembentukan undang-undang (wetgeverende functie atau law making function)..$^{25}$

Di Indonesia, pengertian Undang-Undang adalah Peraturan Perundang-undangan yang dibentuk oleh Dewan Perwakilan Rakyat (DPR) dengan persetujuan bersama Presiden. ${ }^{26}$ Dengan demikian dapat di ketahui bahwa lembaga perwakilan rakyat hanya DPR. Padahal disamping DPR, lembaga perwakilan rakyat di Indonesia juga berupa Dewan Perwakilan Daerah (DPD).

\section{2) Pembentukan Undang Undang Sistem Satu Kamar}

Dalam struktur parlemen tipe unikameral atau satu kamar ini, tidak dikenal adanya dua badan yang terpisah seperti adanya Majelis Tinggi dan Majelis Rendah ataupun DPR dan Senat. Sistem unikameral inilah yang sesungguhnya lebih popular karena sebagian besar negara di dunia sekarang ini menganut sistem ini. ${ }^{27}$

Sistem unikameral dapat diartikan bahwa dalam suatu Rancangan Undang-Undang (RUU) hanya memerlukan pembahasan dan persetujuan satu lembaga legislatif, dengan artian bahwa sistem perwakilan rakyat atau sistem parlemen unikameral merupakan suatu sistem perwakilan dimana hanya ada satu perwakilan dalam lembaga legislatif, dalam pengajuan rancangan undang-undang hanya memerlukan pembahasan dan persetujuan satu lembaga legislatif.

Dalam pelaksanaan sistem unikameral dalam suatu negara baik dalam sistem

22 Moh. Kusnardi dan Harmaily Ibrahim, Pengantar Hukum Tata Negara Indonesia (Jakarta: Pusat Studi HTN FH UI dan CV. Sinar Bakti, 1988), hlm. 140.

$23 \quad$ Ibid., hlm. 143.

24 Jimly Asshiddiqie, op. cit., hlm. 298-199.

25 Ibid., hlm. 299.

26 Pasal 1 angka (3) Undang Undang Nomor 12 Tahun 2011 tentang Pembentukan Peraturan Perundang-undangan, (Lembaran Negara Republik Indonesia Tahun 2011 Nomor 82, Tambahan Lembaran Negara Republik Indonesia Nomor 5234).

27 Jimly Asshiddiqie, Pergumulan Peran Pemerintah dan Parlemen dalam Sejarah: Telaah Perbandingan Konstitusi Berbgai Negara (Jakarta: UI Press, 1996), hlm. 33. 
pemerintahan yang berbentuk presidensial ataupun parlementer, pelaksanaan fungsi parlemen dianggap sangat efisien. Namun hasil dari pelaksanaan fungsi parlemen tersebut secara kualitas kurang ideal karena tidak ada kontrol dari cabang kekuasaan lain dalam parlemen. Dalam rangka mewujudkan representasi baik secara politik, daerah maupun fungsional semuanya digabungkan dalam satu kamar parlemen. ${ }^{28}$

Adapun kelebihan dan keuntungan sistem parlemen/legiislatif unikameral, yaitu: ${ }^{29}$

a) Kemungkinan untuk dengan cepat meloloskan Undang-Undang (karena hanya satu badan yang diperlukan untuk mengadopsi Rancangan-Undang-Undang sehingga tidak perlu lagi menyesuaikan dengan usulan yang berbeda).

b) Tanggung jawab lebih besar (karena anggota legislatif tidak dapat menyalahkan majelis lainnya apabila suatu undang-undang tidak lolos, atau bila kepentingan warga negara terabaikan).

c) Lebih sedikit anggota terpilih sehingga lebih mudah bagi masyarakat untuk memantau mereka; dan

d) Biaya lebih rendah bagi pemerintah dan pembayar pajak.

\section{3) Pembentukan Undang Undang Sistem Dua Kamar}

Beberapa definisi tentang sistem bikameral sebagai berikut: a) Bicameral system: a term pplied by Jeremy Bentham to the division of e legislative body into two chamber, as in the United States Government (Senate and House). ${ }^{30}$

b) Bicameral system: A legislature which has two chamber rather than one (a unicameral system), providing checks and balances and lessening, the risk of elective dictatorship. At the bith of the United, Benjamin Franklin wrote that "aplural legislature is as neccessary to good government as a single executive". ${ }^{31}$

c) Bicameral: The division oflegislature or judicial body into two components or chambers. The US Congress is a bicameral legislature, since its divided into two houses, the Senateand the HouseofRepresentatives. ${ }^{32}$ Pembentukan undang-undang dalam sistem bikameral di Amerika dilakukan melalui dua kamar (House of Representative dan Senate) yang meletakkan keduannya pada fungsi legislasi yang seimbang dan bisa saling melakukan check and balances. Kemudian dimintakan persetujuan ke Presiden.

Apabila Presiden menveto RUU yang telah disetujui oleh kedua kamar di Congress, maka RUU dikembalikan ke Congress yakni ke kamar House of Representative atau Senate sesuai dengan asal diaukannya RUU untuk kemudian di voting.

Apabila hasil voting di kamar asal datangnya RUU tetap memberlakukan RUU dengan dukungan $2 / 3$ suara, maka RUU itu berlaku

\section{Ibid, hlm. 35.}

29 Dhalan Thaib, Menuju Parlemen Bikameral (Studi Konstitusional perubahan ketiga UUD 1945, dalam Abdul Ghofor Anshori dan Sobirin Malian, Membangun Hukum Indonesia, PidatoPengukuhan Guru Besar Ilmu Hukum (Yogyakarta: Kreasi Total Meia, 2008), hlm. 197.

30 Henry Campbell Black, Black's Law Dictionary (Minnesota: West Group, 1991), hlm. 111.

31 Brewr, Brewr's Politics A Phrase And Fable dictionary (London: Nicholas Comfort, 1993).

32 Patricia A. Lewis, The Guide To American Law (Minnesota: West Publishing Co, 1984), hlm. 80-81. 
sebagai UU tanpa harus mendapat peretujuan Presiden.

Proses rancangan undang undang untuk menjadi undang-undang yang sebenarnya membutuhkan berbagai proses yang cukup panjang. Berikut tahapan proses pembuatan UU di Amerika: ${ }^{33}$

\section{Step 1: Introduction}

Only a member of Congress (House or Senate) can introduce the bill for consideration. The Representative or Senator who introduces the bill becomes its "sponsor." Other legislators who support the bill or work on its preparation can ask to be listed as "co-sponsors." Important bills usually have several co-sponsors. Four basic types of legislation, all commonly referred to as "bills" or "measures" are considered by Congress: Bills, Simple Resolutions, Joint Resolutions, and Concurrent Resolutions. A bill or resolution has officially been introduced when it has been assigned a number (H.R. \# for House Bills or S. \# for Senate Bills), and printed in the Congressional Record by the Government Printing Office.

\section{Step 2: Committee Consideration}

All bills and resolutions are "referred" to one or more House or Senate committees according their specific rules. Standing Rules of the US Senate, Rules of the US House of Representatives

\section{Step 3: Committee Action}

The committee considers the bill in detail. For example, the powerful House Ways and Means Committee and Senate Appropriations Committee will consider a bill's potential impact on the Federal Budget. If the committee approves the bill, it moves on in the legislative process. Committees reject bills by simply not acting on them. Bills that fail to get committee action are said to have "died in committee," as many do.

\section{Step 4: Subcommittee Review}

The committeesendssomebillsto asubcommittee for further study and public hearings. Just about anyone can present testimony at these hearings. Government officials, industry experts, the public, anyone with an interest in the bill can give testimony either in person or in writing. Notice of these hearings, as well as instructions for presenting testimony is officially published in the Federal Register.

\section{Step 5: Mark Up}

If the subcommittee decides to report (recommend) a bill back to the full committee for approval, they may first make changes and amendments to it. This process is called "Mark Up." If the subcommittee votes not to report a bill to the full committee, the bill dies right there.

\section{Step 6: Committee Action -- Reporting a Bill}

The full committee now reviews the deliberations and recommendations of the subcommittee. The committee may now conduct further review, hold more public hearings, or simply vote on the report from the subcommittee. If the bill is to go forward, the full committee prepares and votes on its final recommendations to the House or Senate. Once a bill has successfully passed this stage it is said to have been "ordered reported" or simply "reported."

Robert Longley, The U.S. Legislative Process: How Bills Becomes Laws, http://usgovinfo.about.com/od/ uscongress/a/legprocess.htm, (diakses 25 Oktober 2013). 


\section{Step 7: Publication of Committee Report}

Once a bill has been reported (See Step 6:) a report about the bill is written and published. The report will include the purpose of the bill, its impact on existing laws, budgetary considerations, and any new taxes or tax increases that will be required by the bill. The report also typically contains transcripts from public hearings on the bill, as well as the opinions of the committee for and against the proposed bill.

\section{Step 8: Floor Action -- Legislative Calendar}

The bill will now be placed on the legislative calendar of the House or Senate and scheduled (in chronological order) for "floor action" or debate before the full membership. The House has several legislative calendars. The Speaker of the House and House Majority Leader decide the order in which reported bills will be debated. The Senate, having only 100 members and considering fewer bills, has only one legislative calendar.

\section{Step 9: Debate}

Debate for and against the bill proceeds before the full House and Senate according to strict rules of consideration and debate.

\section{Step 10: Voting}

Once debate has ended and any amendments to the bill have been approved, the full membership will vote for or against the bill. Methods of voting allow for a voice vote or a roll-call vote.

\section{Step 11: Bill Referred to Other Chamber}

Bills approved by one chamber of Congress (House or Senate) are now sent to the other chamber where they will follow pretty much the same track of committee to debate to vote. The other chamber may approve, reject, ignore, or amend the bill.

\section{Step12: Conference Committee}

If the second chamber to consider a bill changes it significantly, a "conference committee" made up of members of both chambers will be formed. The conference committee works to reconcile differences between the Senate and House versions of the bill. If the committee cannot agree, the bill simply dies. If the committee does agree on a compromise version of the bill, they prepare a report detailing the changes they have proposed. Both the House and Senate must approve the report of the conference committee or the bill will be sent back to them for further work.

\section{Step 13: Final Action - Enrollment}

Once both the House and Senate have approved the bill in identical form, it becomes "Enrolled" and sent to the President of the United States. The President may sign the bill into law. The President can also take no action on the bill for ten days while Congress is in session and the bill will automatically become law. If the President is opposed to the bill, he can "veto" it. If he takes no action on the bill for ten days after Congress has adjourned their second session, the bill dies. This action is called a "pocket veto."

\section{Step 14: Overriding the Veto}

Congress can attempt to "override" a presidential veto of a bill and force it into law, but doing so requires a $2 / 3$ vote by a quorum of members in both the House and Senate.

\section{Demokrasi Indonesia}

Demokrasi menurut asal kata (etimologie) berarti 'rakyat berkuasa', atau 'pemerintahan oleh rakyat' atau 'government or rule by the people' (kata Yunani, demos berarti rakyat, 
kratos/kratein berarti kekuasaan/berkuasa)". ${ }^{34}$ Menurut Deliar Noer, demokrasi sebagai dasar hidup bernegara memberi pengertian bahwa pada tingkat terakhir rakyat memberi ketentuan dalam masalah-masalah pokok mengenai kehidupannya, termasuk dalam menilai kebijaksanaan negara, karena kebijaksanaan tersebut menentukan kebijaksanaan rakyat. ${ }^{35}$ Jadi, negara demokrasi adalah negara yang diselenggarakan berdasarkan kehendak dan kemauan rakyat, atau jika ditinjau dari sudut organisasi, ia berarti suatu pengorganisasian negara yang dilakukan oleh rakyat karena kedaulatan berada di tangan rakyat. ${ }^{36}$

Apabila ditinjau dari arti katanya, maka hal itu tidak mungkin diwujudkan, karena mustahil orang yang berjumlah lebih banyak memerintah orang yang lebih sedikit. ${ }^{37} \mathrm{Hal}$ ini yang dinamakan demokrasi formil atau demokrasi menurut bentuknya. ${ }^{38}$ Disamping demokrasi formil, terdapat pula demokrasi dari segi isinya atau materinya. ${ }^{39}$

Demokrasi juga dapat dilihat dalam perspektif cara pelaksanaannya. Menurut Andrew Heywood, terdapat dua model sistem atau cara demokrasi, yakni demokrasi langsung (direct democracy) dan demokrasi perwakilan (represntative democracy atau indirect democracy)..$^{40}$ Menurut Sri Soemantri, yang dimaksud indirect democracy adalah suatu demokrasi dimana pelaksanaan kedaulatan rakyat itu tidak dilaksanakan oleh rakyat secara langsung melainkan melalui lembagalembaga perwakilan rakyat. ${ }^{41}$ Menurut Miriam Budiardjo bahwa sistem demokrasi yang terdapat di negara-kota (city-state) Yunani Kuno (abad ke 6 sampai abad ke-3 sebelum Masehi), yaitu suatu bentuk pemerintahan di mana hak untuk membuat keputusan politik dijalankan secara langsung oleh seluruh warga negara yang bertindak berdasarkan prosedur mayoritas. Sifat langsung dari demokrasi Yunani dapat diselenggarakan secara efektif karena berlangsung dalam kondisi yang sederhana, wilayahnya terbatas (negara terdiri dari kota dan daerah sekitarnya) serta jumlah penduduk sedikit ( 300.000 penduduk dalam satu negara kota). Lagipula ketentuan-ketentuan demokrasi hanya berlaku untuk warga negara yang resmi, yang hanya merupakan bagian kecil saja dari penduduk. Untuk mayoritas yang terdiri dari budak belian dan pedagang asing, demokrasi tidak berlaku. ${ }^{42}$

Dalam negara modern, demokrasi tidak lagi bersifat langsung, tetapi demokrasi berdasarkan perwakilan (representative democratic). ${ }^{43}$ Rakyat menunjuk wakil-wakilnya yang menjadi kepercayaannya untuk membawakan kemauan 
rakyat di dalam pemerintahan. Dengan demikian wakil-wakil rakyat inilah yang akan membicarakan maslah-masalah pemerintahan negara. Timbulah asas pemerintahan dengan sistem perwakilan. ${ }^{44}$ Suatu pemerintahan yang berdasarkan atas sistem perwakilan, yang dinamakan representative government. ${ }^{45}$

Dalam sistem politik yang menganut faham komunis, fasis dan nazi, apabila dalam negara yang bersangkutan terdapat lembaga perwakilan rakyatnya, maka lembagaa tersebut tidak dapat berfungsi sebagaimana seharusnya. Lembaga perwakilan itu hanya lembaga yang melegalisasi atau membenarkan semua kebijakan politik yang dijalankan oleh pihak eksekutif, tanpa memberi kritik sedikitpun, lebih-lebih menolak. ${ }^{46}$

Indonesia termasuk negara dengan representative democratic. Hal ini ditegaskan oleh Sri Soemantri bahwa:

"berdasarkan Pasal 1 ayat (2) Undang Undng Dasar1945, ${ }^{48}$ demokrasi yang dianut oleh Undang Undang Dasar 1945 adalah demokrasi dalam arti representative atau indirect democracy, yakni demokrasi dimana pelaksanaan kedaulatan rakyat itu dilaksanakan melalui lembagalembaga perwakilan rakyat seperti Majelis Permusyawartan Rakyat dan Dewan Perwakilan Rakyat". ${ }^{49}$
Setelah amandemen ketiga, lembaga perwakilan rakyat berkembang dengan dibentuknya Dewan Perwakilan Daerah. ${ }^{50}$ Dengan demikian terdapat dua lembaga perwakilan rakyat, yakni Dewan Perwakilan Rakyat (DPR) dan Dewan Perwakilan Daerah (DPD). Menurut Jimly ${ }^{51}$ DPR merupakan perwakilan politik (political representation) dan DPD merupakan perwakilan teritorial (territoril atau regional representation).

Dengan demikian rakyat yang berdaulat. Rakyat yang berdaulat mempunyai kemauan. Dewan perwakilan rakyat dianggap merumuskan kemauan rakyat atau kemauan umum ini dengan jalan menentukan kebijaksanaan umum (public policy) yang mengikat seluruh masyarakat. Undang-undang yang dibuatnya mencerminkan kebijaksanaan-kebijaksanaan itu. ${ }^{52}$

Cabang kekuasaan legislatif adalah yang pertama-tama mencerminkan kedaulatan rakyat. Kegiatan bernegara, pertama-tama adalah untuk mengatur kehidupan bersama. Oleh sebab itu kewenangan untuk menetapkan peraturan itu pertama-tama harus diberikan kepada lembaga perwakilan rakyat atau parlemen atau lembaga legislatif. ${ }^{53}$

Perbedaan antara demokrasi yang satu dengan demokrasi yang lain terletak pada

44 Joeniarto, Demokrasi dan Sistem Pemerintahan Negara (Jakarta: Bina Aksara, 1984), hlm. 23.

45 Sri Soemantri, Op.Cit., hlm. 14.

46 Toto Pandoyo, Ulasan Terhadap Beberapa Ketentuan Undang Undang Dasar 1945: Sistem Politik dan Perkembangan Kehidupan Dempkrasi (Yogyakarta: Liberty, 1985), hlm. 150.

47 Pasal 1 ayat (2) Undang Undang Dasar 1945 menentukan bahwa 'Kedaulatan adalah di tangan rakyat, dan dilakukan sepenuhnya oleh Majelis Permusyawaratan Rakyat'. Setelah amandemen ketiga Pasal 1 ayat (2) berubahmenjadi 'Kedaulatan berada di tangan rakyat dan dilaksanakan menurut UndangUndang Dasar'.

48 Sebelum amandemen UUD NRI 1945.

49 Sri Soemantri, Op.Cit., hlm. 14.

$50 \quad$ Pasal 22 C, dan 22 D UUD NRI 1945.

51 Jimly Assiddiqie, Pengantar Ilmu Hukum Tata Negara Jilid II (Jakarta: Sekretariat Jenderal dan Kepaniteraan Mahkamah Konstitusi Republik Indonesia), hlm. 40.

52 Miriam Budiardjo, Op.Cit., hlm. 173.

53 Jimly Assiddiqie, Op.Cit., hlm. 32. 
isinya (materiil) sedangkan dalam arti formil, maka asasnya tidak terdapat perbedaan, ${ }^{54}$ yaitu menyelenggarakan pemeritahan oleh rakyat. Hal ini ditegaskan oleh Joeniarto yang mengatakan bahwa: ${ }^{55}$

"Walaupun pada asasnya negara-negara yang menjalankan sistem demokrasi ini menyelenggarakan dengan jalan perwakilan, tetapi, cara yang dipergunakan oleh masingmasing negara ternyata banyak berbeda antara negara yag satu dengan negara lainnya, walaupun tentu saja disana sini terdapat juga adanya kesamaan.

Adapun perbedaan itu dapat menunjuk kepada cara penunjukannya daripada wakil-wakil rakyat, dapat pula mengenai cara penyusunannya daripada badan perwakilannya, cara pengambilan keputusannya daripada badan perwakilan, hubungannya antara badan perwakilan dengan badan-badan lainny khususnya badan yang menyelenggarakan pemerintahannya, tugas dan wewenangnya daripada badanbadan perwakilan dan lain-lain lagi. Semua itu menunjukkan bahwa jarang sekali ketatanegaraan sesuatu negara sepenuhnya akan sama dengan ketatanegaraan yang lainnya, walaupun asasnya sama yaitu akan menyelenggarakan suatu sistem pemerintahan oleh rakyat (demokrasi) dengn jalan perwakilan."

Menurut Sri Soemantri, ${ }^{56}$ demokrasi Indonesia secara formil adalah Demokrasi Pancasila. Demokrasi Pancasila adalah kerakyatan yang dipimpin oleh hikmat kebijaksanaan dalam permusyawaratan/ perwakilan yang mengandung semangat Ketuhanan Yang Maha Esa, Kemanusiaan yang adil dan beradab, persatuan Indonesia dan keadilan sosial.

Demokrasi Pancasila tidaklah mungkin dilaksanakan dengan hanya satu cara saja. Pelaksanaan Demokrasi Pancasila harus dihubungkan dengan prakteknya. ${ }^{57}$ Praktek demokrasi Pancasila pasca amandemen dalam perspektif pembentukan undang-undang di Indonesia, ditandai dengan beberapa indikator. Secara spesifik, indikator yang digunakan untuk mengkualifikasikan praktek demokrasi Pancasila adalah fungsi lembaga perwakilan rakyat, yakni apakah lembaga perwakilan rakyat tersebut berfungi atau tidak, artinya bahwa semakin lembaga perwakilan rakyat tersebut berfungi, maka Indonesia semakin demokratis. $\mathrm{Hal}$ ini sesuai dengan pendapat Nomensen Sinamo yang menyatakan bahwa: ${ }^{58}$ semakin banyak melibatkan rakyat dalam keputusan politik yang berkaitan dengan kepentingan rakyat adalah mencerminkan telah makin membaiknya pelaksanaan demokrasi di negara yang bersangkutan.

Untuk meningkatkan fungsi lembaga perwakilan rakyat, yakni agar negara diselenggarakan berdasarkan kehendak dan kemauan rakyat, pada era pasca amandemen UUD 1945 telah diundangkan Undang Undang Nomor 10 tentang Pembentukan Peraturan Perundang-undangan pada tahun 2004. Pada tahun 2011 telah diundangkan Undang Undang Nomor 12 tentang Pembentukan Peraturan Perundang-undangan, dan pada tahun 2012 
Mahkamah Konstitusi telah mengeluarkan putusan Nomor 92/PUU-X/2012.

Perjalanan panjang sebuah undangundang mulai dari tahapan perencanaan ${ }^{59}$ sampai sosialisasi pada masyarakat, pada dasarnya dapat dikelompokkan menjadi 3 (tiga) tahap, yakni tahap Pra Legislasi, tahap Legislasi, dan tahap Pasca Legislasi. Tahap pra legislasi meliputi tahapan perencanaan, dan penyusunan Rancangan Undang Undang. Tahap Legislasi meliputi pembahasan, pengesahan atau penetapan, dan pengundangan. Tahap Pasca Legislasi meliputi dokumentasi, sosialisasi Undang-Undang.

Pada tahap legislasi, kewenangan pembahasan Rancangan Undang-Undang berada pada 3 (tiga) lembaga tinggi negara, yakni Dewan Perwakilan Rakyat (DPR), Dewan Perwakilan Daerah (DPD), dan Presiden. Kewenangan DPR untuk membahas RUU itu, berdasarkan ketentuan Pasal 20 dan Pasal 20A UUD 1945. Pasal 20 ayat (1) menentukan bahwa DPR memegang kekuasaan membentuk undang-undang. Ayat (2) menentukan bahwa Setiap rancangan undang-undang dibahas oleh DPR dan Presiden untuk mendapat persetujuan bersama. Ayat (3) menentukan bahwa jika rancangan undang-undang itu tidak mendapat persetujuan bersama, rancangan itu tidak boleh diajukan lagi dalam persidangan DPR masa itu. Selanjutnya, ketentuan Pasal 20A ayat (1) menentukan bahwa DPR memiliki fungsi legislasi, fungsi anggaran, dan fungsi pengawasan.

Kewenangan pembahasan Rancangan Undang-Undang oleh Dewan Perwakilan Daerah (DPD), ditentukan oleh Pasal 22D ayat (2) UUD 1945,yang menentukan sebagai berikut: Dewan Perwakilan Daerah ikut membahas rancangan undang-undang yang berkaitan dengan otonomi daerah; hubungan pusat dan daerah; pembentukan, pemekaran, dan penggabungan daerah; pengelolaan sumber daya alam dan sumber daya ekonomi lainnya, serta perimbangan keuangan pusat dan daerah; serta memberikan pertimbangan kepada Dewan Perwakilan Rakyat atas rancangan undangundang anggaran pendapatan dan belanja negara dan rancangan undang-undang yang berkaitan dengan pajak, pendidikan, dan agama. Sedaangkan Kewenangan Presiden untuk pembahasan Rancangan Undang-Undang ditentukan oleh Undang-Undang Dasar 1945 Pasal 20 ayat (2) sebagaimana disebutkan di atas.

Pembahasan rancangan undang-undang yang berasal dari DPR atau Presiden dilakukan melalui 2 (dua) tingkat pembicaraan, 60 yakni: ${ }^{61}$ a) Tingkat I dalam rapat komisi, rapat gabungan komisi, rapat Badan Legislasi, rapat Badan Anggaran, atau rapat panitia khusus dan b)

59 Undang Undang Nomor 12 Tahun 2011 tentang Pembentukan Peraturan Perundang-undangan (Lembaran Negara Republik Indonesia Tahun 2011 Nomor 82, Tambahan Lembaran Negara Republik Indonesia Nomor 5234), Pasal 1 angka 1 menentukan bahwa Pembentukan Peraturan Perundang-undangan adalah pembuatan Peraturan Perundangundangan yang mencakup tahapan perencanaan, penyusunan, pembahasan, pengesahan atau penetapan, dan pengundangan.

60 Pasal 148Undang-undang Republik Indonesia Nomor 27 Tahun 2009 tentang Majelis Permusyawaratan Rakyat, Dewan Perwakilan Rakyat, Dewan Perwakilan Daerah, dan Dewan Perwakilan Rakyat Daerah (Lembaran Negara Republik Indonesia Tahun 2009 Nomor 123, Tambahan Lembaran Negara Republik Indonesia Nomor 5043).

61 Ibid., Pasal 149. 
Tingkat II dalam rapat paripurna. Sedangkan pembicaraan Tingkat I dilakukan dengan kegiatan sebagai berikut: ${ }^{62}$ a) pengantar musyawarah; b) pembahasan daftar inventarisasi masalah; dan c) penyampaian pendapat mini.

Dalam pengantar musyawarah, DPR memberikan penjelasan dan Presiden menyampaikan pandangan apabila rancangan undang-undang berasal dari DPR; DPR memberikan penjelasan serta Presiden dan DPD menyampaikan pandangan apabila rancangan undang-undang yang berkaitan dengan kewenangan DPD berasal dari DPR; Presiden memberikan penjelasan dan fraksi memberikan pandangan apabila rancangan undang-undang berasal dari Presiden; atau Presiden memberikan penjelasan serta fraksi dan DPD menyampaikan pandangan apabila rancangan undang-undang yang berkaitan dengan kewenangan DPD berasal dari Presiden. ${ }^{63}$

Daftar inventarisasi masalah diajukan oleh Presiden, apabila rancangan undang-undang berasal dari DPR. Daftar inventarisasi masalah diajukan oleh DPR, apabila rancangan undangundang berasal dari Presiden. ${ }^{64}$ Penyampaian pendapat mini disampaikan pada akhir Pembicaraan Tingkat I oleh: fraksi; DPD, apabila rancangan undang-undang berkaitan dengan kewenangan DPD; dan oleh Presiden. ${ }^{65}$ Dalam hal DPD tidak memberikan pandangan, dan/ atau pendapat mini, Pembicaraan Tingkat I tetap dilaksanakan. ${ }^{66}$
Pembicaraan Tingkat II merupakan pengambilan keputusan dalam rapat paripurna dengan kegiatan: ${ }^{67}$

a. penyampaian laporan yang berisi proses, pendapat mini fraksi, pendapat mini DPD, dan hasil Pembicaraan Tingkat I;

b. pernyataan persetujuan atau penolakan dari tiap-tiap fraksi dan anggota secara lisan yang diminta oleh pimpinan rapat paripurna; dan

c. pendapat akhir Presiden yang disampaikan oleh menteri yang mewakilinya.

Dalam hal persetujuan tidak dapat dicapai secara musyawarah untuk mufakat, pengambilan keputusan dilakukan berdasarkan suara terbanyak. ${ }^{68}$ Dalam hal rancangan undangundang tidak mendapat persetujuan bersama antara DPR dan Presiden, rancangan undangundang tersebut tidak boleh diajukan lagi dalam persidangan DPR masa itu. ${ }^{69}$

Dengan demikian, menurut Jimly Assidiqie, jelaslah bahwa fungsi Dewan Perwakilan Daerah (DPD) itu hanyalah sebagai 'co-legislator' di samping Dewan Perwakilan Rakyat (DPR). Sifat tugasnya hanya menunjang (auxiliary agency) terhadap tugas-tugas konstitusional DPR. Dalam proses pembentukan suatu undang-undang atau legislasi, DPD tidak mempunyai kekuasaan untuk memutuskan atau berperan dalam proses pengambilan keputusan sama sekali. ${ }^{70}$ Artinya bahwa dalam perspektif pembentukan undangundang Pasca Amandemen, Indonesia belum dapat dikatakan sebagai negara demokratis
Ibid., Pasal 150 ayat (1).
Ibid., Pasal 150 ayat (2).
Ibid., Pasal 150 ayat (3).
Ibid., Pasal 150 ayat (4).
Ibid., Pasal 150 ayat (5).
Ibid,, Pasal 151 ayat (1).
Ibid., Pasal 151 ayat (2).
Ibid.) Pasal 151 ayat (3).
Jimly Asshiddiqie, Lembaga Perwakilan dan Permusyawaratan Rakyat Tingkat Pusat, Op.Cit. 
yang baik. Oleh karena praktek demokrasi Pancasila pasca amandemen dalam perspektif pembentukan undang-undang di Indonesia, lembaga DPD sebagai perwakilan rakyat belum berfungsi sebagaimana mestinya, yakni belum berfungsi sebagai lembaga legislator yang sama dengan DPR.

Hal ini berlandaskan pisau analisis bahwa semakin lembaga perwakilan rakyat tersebut berfungsi, maka Indonesia semakin demokratis. Atau dengan kata lain semakin banyak melibatkan rakyat dalam keputusan politik yang berkaitan dengan kepentingan rakyat adalah mencerminkan telah makin membaiknya pelaksanaan demokrasi di negara yang bersangkutan.

Pada tahun 2012, melalui putusan $M K,{ }^{71}$ fungsi DPD berkembang, yakni dalam pembahasan rancangan undang-undang, kedudukan DPD di bidang legislasi setara DPR dan Presiden, bahwa DPD berhak dan/atau berwenang untuk membahas RUU bidang tertentu sejak awal hingga akhir tahapan namun DPD tidak mempunyai kewenangan untuk memberikan persetujuan atau pengesahan RUU menjadi undang-undang. Dengan demikian Indonesia berkembang ke arah yang lebih demoratis.

Ke depan diharapkan pembahasan rancangan undang-undang dilakukan oleh DPR, Presiden dan DPD. Hal ini penting mengingat bahwa sebagai negara yang demokratis dengan sistem perwakilan, lembaga perwakilan rakyat (DPR dan DPD) harus dilibatkan dalam pembahasan rancangan undang-undang.

Ketiga lembaga tinggi negara yakni DPR, Presiden dan DPD harus secara bersama- sama membahas Rancangan Undang Undang dari pembahasan tingkat I sampai dengan persetujuan atau penolakan pada rapat paripurna. DPR dan DPD dalam pembahasan rancangan undang-undang adalah sebagai lembaga perwakilan rakyat, bukan sebagai Majelis Permusyawratan Rakyat. oleh karena kewenangan DPD dan DPR sebagai lembaga perwakilan rakyat berbeda dengan kewenangan DPR dan DPD sebagai Majelis Permusyawaratan Rakyat.

\section{E. Penutup}

\section{Kesimpulan}

Demokrasi Indonesia pada masa pasca amandemen UUD 1945 masih berkembang, artinya Indonesia belum dapat dikatakan sebagai negara yang demokratis. Hal ini mengingat bahwa Indonesia sebagai negara demokratis yang diselenggarakan berdasarkan representative democratic, dalam perspektif pembentukan undang-undang, seharusnya dalam pembahasan rancangan undangundangnya melibatkan rakyat melalui perwakilannya, terutama DPD.

\section{Saran}

Ke depan diharapkan dengan amandemen ke V (lima) UUD 1945, Indonesia akan lebih demokratis, dengan lebih memperbesar fungsi DPD. Model pembahasan rancangan undangundang oleh tiga lembaga tinggi negara, yakni DPR, DPD dan Presiden, lebih cocok diterapkan di Indonesia. Hal ini disebabkan karena: i) Indonesia tidak mengenal sistem veto seperti

71 Putusan Mahkamah Konstitusi Republik Indonesia Nomor 92/PUU-X/2012. 
di Amerika; ii) Lebih demokratis, dan iii) Biaya pembuatan undang-undang dapat lebih ditekan.

\section{DAFTAR PUSTAKA}

\section{Buku}

Alwi, Hasan (Pemred.), Kamus Besar Bahasa Indonesia, Edisi Ketiga, (Jakarta: Pusat Bahasa Departemen Pendidikan Nasional dan Balai Pustaka, 2005).

Asshiddiqie, Jimly, Perihal Undang-undang, (Jakarta: Konstitusi Press, 2006), hlm. 213.

Asshiddiqie, Jimly, Pengantar IImu Hukum Tata Negara, (Jakarta: PT Rajagrafindo Persada, 2013).

Asshiddiqie, Jimly, Pergumulan Peran Pemerintah dan Parlemen dalam Sejarah: Telaah Perbandingan Konstitusi Berbgai Negara (Jakarta: UI Press, 1996).

Asshiddiqie, Jimly, Pengantar IImu Hukum Tata Negara Jilid II (Jakarta:Sekretariat Jenderal dan Kepaniteraan Mahkamah Konstitusi Republik Indonesia).

Bakker, Anton dan Achmad Charris Zubair, Metodologi Penelitian Filsafat, (Yogyakarta: Kanisius, 1990).

Benn, S.I. dan Peters, Principles of Political Thought (New York: Collier Books, 1964).

Black, Henry Campbell. Black's Law Dictionary (Minnesota: West Group, 1991).

Bogdan, Robert dan Steven J. Taylor, Introduction to qualitative Research Methods: A Phenomenological Approach To The Social Science (Toronto: A Willey-Interscience Publication, 1975).

Brewr, Brewr's Politics A Phrase And Fable Dictionary (London: Nicholas Comfort, 1993).

Creswell, John W., Research Design: Qualitative \& Quantitative Approaches, (New Delhi: Sage Publication, 1994).

Heywood, Andrew, Political Theory: An Introduction (England: Palgrave, 1999).

Joeniarto, Demokrasi dan Sistem Pemerintahan Negara (Jakarta: Bina Aksara, 1984).

Kusnardi, Moh. dan Harmaily Ibrahim, Pengantar Hukum Tata Negara Indonesia (Jakarta: Pusat Studi HTN FH UI dan CV. Sinar Bakti, 1988).

Lewis, Patricia A., The Guide To American Law (Minnesota: West Publishing Co, 1984).

Moleong, Lexy J., Metodologi Penelitian Kualitatif (Bandung: PT Remaja Rosdakarya, 1989).
Noer, Deliar. Pengantar ke Pemikiran Politik (Jakata: CV. Rajawali, 1983).

Pandoyo, S. Toto, Ulasan Terhadap Beberapa Ketentuan Undang Undang Dasar 1945: Sistem Politik dan Perkembangan Kehidupan Dempkrasi (Yogyakarta: Liberty, 1985).

Patton, Michael Quinn, Qualitative Evaluation And Research Methods, Second Edition (New Delhi: Sage Publication, 1980).

Philips, O. Hood, Paul Jackson, dan Patricia Leopold, Constitution and Administrative Law (London: Sweet \& Maxwell, 2001).

Sinamo, Nomensen, Hukum Tata Negara: Suatu Kajian Kritis tentang Kelembagaan Negara (Jakarta: Permata Aksara, 2012).

Strauss, Anselmus dan Juliat Corbin, Basic of Qualititive Research, Grounded Theory Procedure and Thechnique (New Delhi: Sage Publication, 1979).

Soekanto, Soerjono dan Sri Mamuji, Penelitian Hukum Normatif,Suatu Tinjauan Singkat (Jakarta: CV. Rajawali, 1990).

Soemantri, Sri, Tentang Lembaga-lembaga Negara Menurut UUD 1945 (Bandung: Alumni, 1986).

Sugono, Dendy, Kamus Bahasa Indonesia (Jakarta: Pusat Bahasa Departemen Pendidikan Nasional, 2008).

Thaib, Dhalan, Menuju Parlemen Bikameral (Studi Konstitusional perubahan ketiga UUD 1945, dalam Abdul Ghofor Anshori dan Sobirin Malian, Membangun Hukum Indonesia, pidato Pengukuhan Guru Besar IImu Hukum (Yogyakarta: Kreasi Total Meia, 2008).

\section{Makalah / Artikel / Prosiding / Hasil Penelitian}

Amirmachmud. Demokrasi, Undang Undang dan Peran Rakyat, dalam PRISMA No. 8 (Jakarta: LP3ES, 1984).

\section{Internet}

Jimly Asshiddiqie, "Lembaga Perwakilan dan Permusyawaratan Rakyat Tingkat Pusat", www. jimly.com\%2Fmakalah\%2Fnamafile\%2F40\%2F Trikameralisme_DPD.doc\&ei=QGahUtupLI6FrA fdmID4AQ\&usg=AFQjCNFRM9KUgqOStyoqjITa Vbj6pySjfA\&sig2=uYgaWYY9nW4zY8N3Gsf1Tg, (diakses 16 Nopember 2013).

Robert Longley, "The U.S. Legislative Process: How Bills Becomes Laws", http://usgovinfo.about. 
com/od/uscongress/a/legprocess.htm, (diakses tanggal 25 Oktober 2013).

\section{Peraturan}

Undang Undang Dasar Negara Republik Indonesia Tahun 1945.

Undang Undang Nomor 12 Tahun 2011 tentang Pembentukan Peraturan Perundang-undangan, (Lembaran Negara Republik Indonesia Tahun 2011 Nomor 82, Tambahan Lembaran Negara Republik Indonesia Nomor 5234).
Undang-Undang Nomor 27 Tahun 2009 tentang Majelis Permusyawaratan Rakyat, Dewan Perwakilan Rakyat, Dewan Perwakilan Daerah, dan Dewan Perwakilan Rakyat Daerah (Lembaran Negara Republik Indonesia Tahun 2009 Nomor 123, Tambahan Lembaran Negara Republik Indonesia Nomor 5043).

\section{Putusan}

Putusan Mahkamah Konstutusi Republik Indonesia Nomor 92/PUU-X/2012 